\title{
IAMJ
}

INTERNATIONAL

AYURVEDIC

MEDICAL JOURNAL

\section{PREGNANCY CARE IN COVID19 THROUGH AYURVEDA}

\author{
Mrityunjoy Baroi ${ }^{1}$, Dipak Kr. Goswami ${ }^{2}$
}

${ }^{1}$ PG Scholar, Dept of Prasuti Tantra Evum Stree Roga, Govt. Ayurvedic College and Hospital, Jalukbari, Guwahati-14, Assam, India, ${ }^{2}$ assistant Professor, Dept of Prasuti Tantra Evum Stree Roga, Govt. Ayurvedic College and Hospital, Jalukbari, Guwahati-14, Assam, India

Corresponding Author: mrityunjoybaroi@gmail.com

\section{https://doi.org/10.46607/iamj09p6012021}

(Published online: November 2021)

Open Access

(C) International Ayurvedic Medical Journal, India 2021

Article Received: 01/10/2021 - Peer Reviewed: 09/10/2021 - Accepted for Publication: 11/10/2021

\begin{abstract}
The coronavirus disease 2019 (COVID-19) is a highly transmittable and pathogenic viral infection caused by severe acute respiratory syndrome coronavirus 2 (SARS COV-2) and Garbha-Kala is one of the most crucial and responsible stages in women's life. COVID-19 can produce a devastating effect on maternal wellbeing. Ayurveda has mentioned the pandemic situation under the term Janapadodhwamsa which spread through Vayu, Jala, Desha and Kala. The outbreak of Covid-19 is severely affecting the world. It is an infectious disease caused by severe acute respiratory syndrome coronavirus 2 . It has mainly respiratory and systemic manifestations. People having diabetes, chronic diseases, pregnant women are more prone to this infection as they are more susceptible to pathogens and the development of severe conditions like pneumonia. Due to the physiological changes during pregnancy, pregnant women are the most vulnerable group in this pandemic situation because infection during pregnancy can result in adverse outcomes. Much research is still in continuation because we are not sure of much evidence till now. Many preventive protocols suggested by Ayurveda can prevent the prevalence of disease up to some extent.
\end{abstract}

Keywords: Ayurveda, Covid-19, Janapadodhwamsa, Pandemic, Pregnancy 


\section{INTRODUCTION}

The current health scenario of the whole world facing crises of a pandemic outbreak caused by novel Coronavirus. It is an RNA virus, and the incubation period is 2-14 days. Investigation for coronavirus needed nasal swab and sputum sample. Diagnosis can be done through RT- PCR and computed tomography and rapid antigen test. The virus first multiplies in the throat and afterwards in the lungs. It is a highly contagious and infectious disease that causes illnesses such as common cold to severe pneumonia and sometimes death also. Ayurveda considers it as a Janapadodhwamsa. It can be grouped under the class of $a a$ gantuja vikara with special reference to the class of bhutabhishangaj (microbiological aetiology). It may be defined as samsargaj roga (communicable disease) i.e., the disease which is communicable due to a history of contact with a person who is affected. Pregnancy has always been at higher risk in pandemics and even in seasonal influenza. Due to the Sansargaja nature of Covid-19, old, aged people, a person suffering from diabetes, chronic diseases; pregnant ladies are considered as the high-risk group.

\section{PREGNANCY AS A HIGH-RISK FACTOR}

Pregnancy is placed in the high-risk group during pandemics due to certain reasons:

- During pregnancy, several changes occur in the body especially physiological changes which affect various organs of the body such as respiratory, cardiovascular system, immune system etc.

- Certain anatomical changes also occur like changes in the diameter of the thoracic cavity and the level of the diaphragm. Some changes like increased heart rate, oxygen usage, decrease in lung capacity are also observed.

- During pregnancy, the body becomes more prone to infections (virus, bacteria) due to the shift of cell-mediated immunity to humoral immunity.

- There are chances of vertical transmission (from mother to foetus) which raises the concern towards the infectious diseases

- Foetus does not develop immunity properly thus it is most susceptible to infections.
- In case of infection, deregulation of cytokines can hamper the neurological development of the foetus

\section{MATERIALS AND METHODS}

In this review article, we have studied all articles about COVID-19 and pregnancy from December 2019 to August 2021 published in various journals as information about COVID-19 is not available in books yet and reviewed them. The Ayurvedic data is collected from Samhita.

\section{SYMPTOMS-}

Generally, patients have -

- Fever (Jwara),

- $\operatorname{Cough}($ Kasa),

- Myalgia (Angamarda),

- Fatigue (Tandra),

- Dysnoea (Shwas),

- Laboured breathing (shrama shwas).

Considering all these factors COVID-19 can be considered as sannipata jwara. There are 13 types of sannipata jwara as mentioned in charak samhita. From that we can correlate it with kaphapradhan, pittamadhya, vatahin and kaphapradhan, vatamadh$y a$, pittahin. It can be correlated with symptoms of kaphavataj jwara. But as it progresses it becomes fatal i.e., Sannipata Jwara.

\section{PREVENTION PROTOCOL IN PREGNANT WOMEN-}

As there is no definite medicine for COVID-19 as of now, it will be good to take preventive measures which boost immunity. Prevention is always better than cure. Pregnant women should follow this protocol as they are on the verge of high risk. Ayurvedic protocol for the prevention of COVID-19 from Samhita to maintain proper health is as below. It is recommended by the Ministry of AYUSH. Some additions were done in it by considering the health of a pregnant woman

\section{AHARA (DIET)}

- Laghu ahara (light diet), cooked vegetables, a soup made up of green gram, phulaka, chapatti, moog 
- Daal krushra (kitchari) with green vegetables, less rice, homemade food

- Hot milk with half a teaspoon of haridra (turmeric)

- Warm water for drinking

- Avoid spicy, oily food

- Avoid dairy products and cold drinks

VIHARA (LIFESTYLE)

- Nidra-8-9-hour sleep at night, take complete rest, avoid sleeping in the day (diwaswap varjya)

- Vyayam- Do pranayama regularly at morning

- Gandush (gargling) - With water boiled with haridra and lavana (salt) or do oil pulling therapy i.e., take 1 tablespoon coconut oil in the mouth.

- Snan- Daily bath with warm water

- Nasya- Apply coconut oil in both nostrils (pratimarsh nasya)

- Steam inhalation- With tulsi (holy basil) and haridra

- Dhoopan (room fumigation)-with guggul (Commiphora mukul), nimba (Azadirachta indica), vacha (Acorus calamus)

In Ayush Guidelines of covid19, they created 4 target groups and the pregnancy grouped under 3 Target groups i.e. Vulnerable Group (Pregnant \& Lactating women, Children \& Geriatric subjects) Children, pregnant women, elderly people, malnourished people, and people who are ill or immune-compromised, are particularly vulnerable to any health disasters and they face a relatively high risk of the disease burden associated with emergencies. These groups of the population need special care in terms of prevention and management. The best way of prevention is boosting immunity and here are some proven immune boosters or Rasayana drugs that can be prescribed to the vulnerable groups. Postpartum and lactating women may continue with feeding the baby, and a prophylactic dose may be given to breastfed children also. The following are some of the commonly prescribed Rasayana drugs in each category, however, Physicians should confirm the absence of fever and other symptoms and the appetite is im- proved, if appetite is poor Deepana and Pachana drugs may be added.

\section{RASAYANA FOR PREGNANT AND LACTAT- ING WOMEN}

The following drugs may be used specifically in pregnancy and lactating women:

- Phala Sarpis - 10 - 12gm in two divided doses with warm water

- Kalyanaka Ghrita- 10 - 12gm in two divided doses with warm water

- Ashwagandha Rasayana - 10 -12 gm twice daily with warm milk.

- Soubhagya Shunti Leha- 10 - 12 gm twice daily with warm milk on empty stomach

- Daily use of Milk with Ghee (cup of milk with a teaspoon of ghee)

\section{DISCUSSION}

COVID-19 is a highly contagious and infectious disease. The only key to a healthy life is to follow preventive measures. Like the general population, pregnant women, in the same way, can be exposed to pathogenic organisms. However physiological and pathological changes in pregnancy make women more vulnerable to infection. Even a relatively minor infection can threaten the lives of both mother and fetus. COVID-19 infection that occurs during pregnancy presents a serious problem above and beyond those normally associated with the disease. So here we have discussed the COVID-19 pandemic, coronavirus, its diagnosis, pharmaceutical care. The Ayurvedic correlation is also discussed.

\section{CONCLUSION}

The disease COVID-19 can be considered as the clinical congruence of Samsannipataja jwara. It comes under Janapada dhamsa vikara and can be grouped in Bhutabhisanga Agantuja Vikara (external cause of microbes) The diet and lifestyle which are described thousands of years ago in Ayurveda is beneficial and one can follow it for the prevention of COVID-19 in pregnancy. This article gives priority to the reduction of transmission of COVID-19 in pregnant women. 


\section{TAKE HOME MESSAGE}

- Attend to the three pillars- Nutrition, Sleep and Lifestyle

- Eat healthily, be healthy- eating an immunityboosting diet

- Maintain good sleep and hygiene

- Do exercise /yoga/Meditation

- Nasya, Gandoosh and Massage yourself every day

- Support your health with Rasayan

- Staying healthy and panic-free

\section{REFERENCES}

1. Liang $\mathrm{H}$, Acharya $\mathrm{G}$, (Novel coronavirus disease COVID-19 in pregnancy: what clinical recommendations to follow?) Acta Obstet Gynecol Scand, 2020 April; 99(4): 439-442.

2. Mojgan Karimi-Zarchi et. al, (Vertical Transmission of Coronavirus Disease 19 (COVID-19) from Infected Pregnant Mothers to Neonates: A Review) Taylor\& Francis, 2020 April. https://www.tand fonline.com /DOI/full/10.1080/15513815. 2020.1747120

3. Dr Brahmanand Tripathi, Editor. Charak Samhita Bhag-1, Vimansthan adhyay $3 / 5$, Chaukhamba prakashan, Varanasi, reprinted, 2012.

4. Dr Brahmanand Tripathi, Editor. Charak Samhita Bhag-2, Chikitsa sthan adhyay 3/115, Chaukhamba prakashan, Varanasi, reprinted, 2014.

5. Dr Brahmanand Tripathi, Editor. Charak Samhita Bhag-1, Sutrasthan adhyay 18/44, Chaukhamba prakashan, Varanasi, reprinted, 2012.

6. Dr Brahmanand Tripathi, Editor. Charak Samhita Bhag-2, Chikitsa sthan adhyay 3/97, Chaukhamba prakashan, Varanasi, reprinted, 2014.

7. Dr Brahmanand Tripathi, Editor. Charak Samhita Bhag-2, Chikitsa sthan adhyay 3/100, Chaukhamba prakashan, Varanasi, reprinted, 2014.

8. Kaviraj Atridev Gupt, commentator. Shree Vaghbhat rachitam Ashtang hrudayam, Nidansthan adhyay 2/25, Chaukhambha prakashan, Varanasi.

9. Dr Brahmanand Tripathi, Editor. Charak Samhita Bhag-2, Chikitsa sthan adhyay 3/103-107, Chaukhamba prakashan, Varanasi, reprinted, 201.

10. Immunity boosting AYUSH Advisory. pdf https://www.mohfw.gov.in.

11. AYUSH Guideline for covid 19 given in www.ayush.gov.in

\section{Source of Support: Nil Conflict of Interest: None Declared}

How to cite this URL: Mrityunjoy Baroi \& Dipak Kr. Goswami: Pregnancy Care In Covid19 Through Ayurveda. International Ayurvedic Medical Journal \{online\} 2021 \{cited November 2021\} Available from: http://www.iamj.in/posts/images/upload/3219 3222.pdf 